"Obstacles of human resource planning that affect workers in delivering quality services"

\begin{tabular}{|c|c|}
\hline AUTHORS & Njabulo Khumalo iD https://orcid.org/0000-0002-7480-6715 \\
\hline ARTICLE INFO & $\begin{array}{l}\text { Njabulo Khumalo (2019). Obstacles of human resource planning that affect } \\
\text { workers in delivering quality services. Problems and Perspectives in } \\
\text { Management, 17(2),114-123. doi:10.21511/ppm.17(2).2019.08 }\end{array}$ \\
\hline DOI & http://dx.doi.org/10.21511/ppm.17(2).2019.08 \\
\hline RELEASED ON & Thursday, 25 April 2019 \\
\hline RECEIVED ON & Friday, 02 November 2018 \\
\hline \multirow[t]{2}{*}{ ACCEPTED ON } & Monday, 21 January 2019 \\
\hline & $(\mathrm{cc}) \mathrm{EY}$ \\
\hline LICENSE & $\begin{array}{l}\text { This work is licensed under a Creative Commons Attribution } 4.0 \text { International } \\
\text { License }\end{array}$ \\
\hline JOURNAL & "Problems and Perspectives in Management" \\
\hline ISSN PRINT & $1727-7051$ \\
\hline ISSN ONLINE & $1810-5467$ \\
\hline PUBLISHER & LLC "Consulting Publishing Company "Business Perspectives" \\
\hline FOUNDER & LLC "Consulting Publishing Company "Business Perspectives" \\
\hline
\end{tabular}

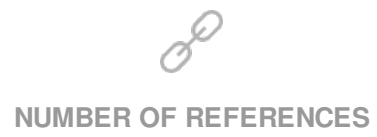

24

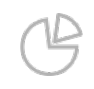

NUMBER OF FIGURES

0

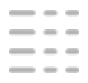

NUMBER OF TABLES

12

(C) The author(s) 2023. This publication is an open access article. 


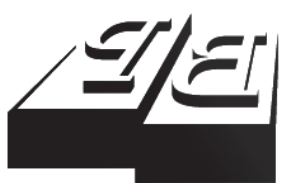

BUSINESS PERSPECTIVES

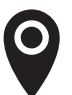

LLC "CPC "Business Perspectives" Hryhorii Skovoroda lane, 10, Sumy, 40022, Ukraine

www.businessperspectives.org

Received on: $2^{\text {nd }}$ of November, 2018 Accepted on: $21^{\text {st }}$ of January, 2019

(C) Njabulo Khumalo, 2019

Njabulo Khumalo, Ph.D., Lecturer, Graduate School of Business and Leadership, University of KwaZulu-Natal, M.Com-University of Zululand, B. Tech HRM, N. Diploma-Mangosuthu University of Technology, South Africa.

\section{OBSTACLES OF HUMAN RESOURCE PLANNING THAT AFFECT WORKERS IN DELIVERING QUALITY SERVICES}

\begin{abstract}
The paper aimed to identify the obstacles of Human Resource Planning (HRP) that affect workers in delivering quality services to public within the customer centres of the municipality located in South Africa (SA). Since, HRP is well known as a tool that resolves the existing and future organization obstacles by confirming that the right employees are placed in the right positions at the right time. The investigation of the paper used mixed methods, which encompasses both qualitative and quantitative methods in its data collection. From the target, only 45 workers completed a questionnaire and only seven supervisors participated in one-on-one interviews. Results reveal the lack of both internal and external factors, which in clude a shortage of workers to perform the duties of the municipal in the customer centres. This includes demographic issues, lack of education qualifications, recruitment policies, insufficient working tools, working environment and career growth. The recommendation is to implement a strategical recognition for good performance to workers and to look for other venues with enough space to deliver quality services. Lastly, there is a need to establish and implement strategies of promotion and growth within the municipality.
\end{abstract}

Keywords

employment, worker, human resource, skill, managers, government policy services

JEL Classification L L88, O15

\section{INTRODUCTION}

Few studies that have been conducted under the concept of Human Resource Planning (HRP) and some were on the private sector. To date, no study has been done in the public sector that investigates the obstacles of HRP, which affect the municipal workers in delivering quality service to public. Due to budgetary and time constraints, this paper is focused only on the customer centres of the municipality located in KwaZulu-Natal (KZN) province in South Africa (SA). From the findings of the research that was conducted by the Human Resource Management of the Public Services, in terms of the productivity, SA was rated last. One of the major challenges facing services organizations such as municipality today is to deliver quality services to people (Mokhlis, Aleesa, \& Mamat, 2011). Ndebele and Lavhelani (2017) found that poor service delivery is a result of financially misusing of resources. While, Mpofu and Hlatywayo (2015) found that to improve workers performance and provision of basic services to public, there as a need for effective training and development systems in the municipal environment. 
Poor service delivery is a consequence of the interference of political manipulation of councilors, poor policies of human resources (HR), poor planning in the municipalities and lack of worker capacity (Makanyeza, Hardson, Kwandayi, Beatrice, \& Nyaboke, 2012). As a result of this, no strategy was implemented to build workers' motivation and engagement to increase productivity. The employers are very much crucial for municipal service institutions, as workers interact directly and indirectly with public who assess, criticize and publicize the quality of service received (Dzansi, 2010). The study on the role of HRP practices in employee performance in country governments in Kenya, reveals that competitive remuneration was a factor that affects HRP in the improvement of performance (Maina \& Kwasari, 2015). However, the study done by Anzam (2013) reveals that processes and practices were found not to be strategic in the public sector organizations, but effective HRP is a solution that combines and deals with the internal and external issues of the organization. The aim of HRP is to consider on internal and external demand and supply of employees to achieve the organization requirements in a form of dealing with the available and required factors (Santos, Zhang, Gonzalez, \& Byde, 2009).

\section{LITERATURE REVIEW}

\subsection{Service delivery}

According to Nealer (2014), the responsibility of the municipality is to deliver services to public as government collects taxes from people and organizations. Stredwick (2005) reveals that one of the major challenges on SA municipalities is poor performance and corruption by the workers. Pretorius and Schurink (2007) emphasize that it is privilege of people to access effective services. The report of the State of the Local Government in South Africa (2009) indicates that SA had about 36 municipalities that do not have a sanitation backlog. Community Survey Report (2007) reveals that KZN was counted as one of the provinces recorded as the lowest to access piped water below the national average of $74.4 \%$ "The enormity of service delivery challenges saddling municipalities remain daunting. Further the performance of municipalities should be located within the context of the unique challenges faced by weaker and more vulnerable municipalities characterized by complex rural development problems, including massive infrastructure backlogs that require extraordinary measures to address funding and delivery capacity requirements" (Koma, 2010, p. 114). Burger (2010) and Ngcamu (2013) found that some workers in the municipality are not qualified enough to resume the duties of the required standard.
On the other hand, successful municipality has skilled and qualified workers at all levels that contribute significantly well to the community. Training and development of workers ensure that the municipality is in the levelof improving the skills of employees in order to deliver according to government regulations (Nisha, 2009). The study conducted by Mpofu and Hlatywayo (2015) found that the improvement of performance of the municipality through its workers requires high quality training and development programs. It further recommends that municipality needs to increase a number of workers to be trained and introduce motivational incentives for such development. Mdlongwa (2014) indicates that service delivery challenges of local government impact on HR in terms of capacity and competences. Some municipalities in SA have workers with no required technical skills and also there is a shortage of skilled workers who render quality services to public. As a result local government can address these challenges of service delivery by increasing awareness and education program, investigating the officials who are corrupt, making clear efforts through improved modes of communication and learning to obey the laws of the country (Mdlongwa, 2014). Mugambi (2014) indicates that the set of principles of service delivery framework consists of standards and policies to develop, deploy and plan for retirement of service deliverers. The municipal customer care centers aim to ensure that all customers experience standard of service excellence. This aim displays and ensures customer first and excellence in delivering all municipal services to its people. 
Workers have common set of espoused values that guide their interaction with public, including respect, good customer care, service excellence, integrity and professionalism, mutual trust and understanding (IDP/14/15).

\subsection{Factors of HRP}

According to Colley and Price (2010), HRP process has been applied by very few public sector organizations in many countries, including Australia. Government experience a huge challenge of retaining and attracting skilled employees. As a result, organizations should provide competitive incentives and plan for the future of worker's need, which includes insurance protections for workers, healthy environment, salaries and career growth opportunities (Maina \& Kwasira, 2015), while Ghazala and Habib (2012) emphasize that HRP shapes the organization to have workers with competencies required to achieve the institutional goal. HRP deals with bigger issues of the methods of employment and development of workers more effectively for the achievement of the organizational goals.

Colley and Price (2010) found that economic changes was one of the factors that dominate in Malaysian construction industry, while Xie and Haung (2012) revealed technology as a factor, which may lead to training the existing workers or firing and appointing new workers due to technology change. Employers prefer skilled workers who can be parallel with technology change. Demographics is regarded as a factor that affects the effectiveness of HRP such as age, gender and ethnicity, therefore, balancing of skilled labor in the organization, both male and female, should be considered, as well as age (Norma-Major \& Gooden, 2012). The studies of Jacobson (2010) and Ulfertsm, Wirtz, and Peterson (2009) recommend that the demographics issues need to be addressed in the public sector organisations. Macharia (2016) reveals that setting up a new regional organization and planning for new methods of working are factors that affect HRP. Promotions, scarce and critical competencies were other factors that affect HRP.

Organizations that have a shortage of workers end up on suffering from meeting the target, use of overtime, recalling employees who were laid off, use of part time and subcontracting, which cost the organization (Jacobson, 2010). Xie and Haung (2012) indicate that the cooperation encouragement of education institutions will enhance service provision. Standard procedure of hiring foreign labor, as well as workers' skills, reflect the wages level. High market demand skilled labor and the growth of the economy impact on the workers to support their daily expenses due to the increase of products' price. Weak global economy causes the organization to fail to achieve the projected growth rate or target.

The paper aimed to investigate the obstacles that affect the success of HRP through workers in delivering quality services within the customer centres of the municipality located in $\mathrm{KZN}$ in SA.

\section{METHODOLOGY}

Participants were divided into two groups: large and small. The large group participated in the quantitative part where it was given a questionnaire, which was constructed to give a clear picture about the research and the other group was small, consisting of few members to participate on-one-on one interviews in order to get better understanding on the research. Closed-ended questionnaire was distributed to the sample of 56 workers and interviews were conducted to seven supervisors of the customer centres of the all the areas of the municipality in the province of KZN in SA. Therefore, all employees had equivalent chance to contribute to this research, so simple random sample was adopted. For the qualitative party, sampling technique used was census, because the researcher felt that all seven members, which were supervisors, had to participate. Both instruments were printed in English as average language of communication by workers to communicate in the customer centres of the municipality. From 56 questionnaires distributed, only 45 returned, which is 80 percent response rate, and were analyzed through SPSS version 24 and all recordings from the interviews were coded into themes through MS Word. 


\section{RESULTS}

Table 1. Frequency showing the demographics based on race, gender and age group

\begin{tabular}{|c|c|c|c|c|}
\hline Demographics & Frequency & Percent & Valid percent & Cumulative percent \\
\hline \multicolumn{5}{|c|}{ Race } \\
\hline Black people & 38 & 84.4 & 84.4 & 84.4 \\
\hline Coloured people & 1 & 2.2 & 2.2 & 86.7 \\
\hline Indian people & 5 & 11.1 & 11.1 & 97.8 \\
\hline White people & 1 & 2.2 & 2.2 & 100.0 \\
\hline Total & 45 & 100.0 & 100.0 & - \\
\hline \multicolumn{5}{|c|}{ Gender } \\
\hline Female employees & 31 & 68.9 & 68.9 & 68.9 \\
\hline Male employees & 14 & 31.1 & 31.1 & 100.0 \\
\hline Total & 45 & 100.0 & 100.0 & - \\
\hline \multicolumn{5}{|c|}{ Age group } \\
\hline 24 years and less & 2 & 4.4 & 4.4 & 4.4 \\
\hline $25-35$ years & 23 & 51.1 & 51.1 & 55.6 \\
\hline $36-40$ years & 10 & 22.2 & 22.2 & 77.8 \\
\hline Over 46 years & 10 & 22.2 & 22.2 & 100.0 \\
\hline Total & 45 & 100.0 & 100.0 & - \\
\hline \multicolumn{5}{|c|}{ Gender } \\
\hline Female & 31 & 68.9 & 68.9 & 68.9 \\
\hline Male & 14 & 31.1 & 31.1 & 100.0 \\
\hline Total & 45 & 100.0 & 100.0 & - \\
\hline \multicolumn{5}{|c|}{ Qualifications } \\
\hline National certificate & 22 & 48.9 & 48.9 & 48.9 \\
\hline National diploma & 13 & 28.9 & 28.9 & 77.8 \\
\hline B. Tech & 4 & 8.9 & 8.9 & 86.7 \\
\hline B. Degree & 4 & 8.9 & 8.9 & 95.6 \\
\hline B. Degree (Hons) & 2 & 4.4 & 4.4 & 100.0 \\
\hline Total & 45 & 100.0 & 100.0 & Total \\
\hline
\end{tabular}

Table 1 reveals that the majority of the participants were Black people. In terms of gender, female employees were dominating. For age, participants were in the age of 25-35 years. Most of the qualification participants had were national certificate.

Table 2. Frequency showing the equipment and tools

\begin{tabular}{l|c|c|c|c}
\hline \multicolumn{1}{c|}{ Equipment and tools } & Frequency & Percent & Valid percent & Cumulative percent \\
\hline Strongly agree & 14 & 31.1 & 31.1 & 31.1 \\
Agree & 22 & 48.9 & 48.9 & 80.0 \\
Neutral & 4 & 8.9 & 8.9 & 88.9 \\
Strongly disagree & 5 & 11.1 & 11.1 & 100.0 \\
Total & 45 & 100.0 & 100.0 & - \\
\hline
\end{tabular}

Table 2 reveals that the majority of the participants agreed that there are enough equipment and tools to work.

Table 3. Frequency showing the equipment repair

\begin{tabular}{l|c|c|c|c}
\hline \multicolumn{1}{c|}{ Equipment repair } & Frequency & Percent & Valid percent & Cumulative percent \\
\hline Strongly agree & 8 & 17.8 & 17.8 & 17.8 \\
\hline Agree & 20 & 44.4 & 44.4 & 62.2 \\
Neutral & 11 & 24.4 & 24.4 & 86.7 \\
Disagree & 2 & 4.4 & 4.4 & 91.1 \\
Strongly disagree & 4 & 8.9 & 8.9 & 100.0 \\
Total & 45 & 100.0 & 100.0 & - \\
\hline
\end{tabular}

Table 3 reveals that the majority agree that equipment are repaired faster within the centers of the municipality. 
Table 4. Frequency showing the communication and interactive skills coaching

\begin{tabular}{l|c|c|c|c}
\hline $\begin{array}{c}\text { Communication and interactive skills } \\
\text { coaching }\end{array}$ & Frequency & Percent & Valid percent & Cumulative percent \\
\hline Strongly agree & 17 & 37.8 & 37.8 & 37.8 \\
Agree & 23 & 51.1 & 51.1 & 88.9 \\
\hline Neutral & 1 & 2.2 & 2.2 & 91.1 \\
Disagree & 1 & 2.2 & 2.2 & 93.3 \\
\hline Strongly disagree & 3 & 6.7 & 6.7 & 100.0 \\
\hline Total & 45 & 100.0 & 100.0 & - \\
\hline
\end{tabular}

Table 4 reveals that the majority agree that they were taught on communication and interactive skills coaching.

Table 5. Frequency showing the managers support if there are problems

\begin{tabular}{l|c|c|c|c}
\hline Managers support if there are problems & Frequency & Percent & Valid percent & Cumulative percent \\
\hline Strongly agree & 13 & 28.9 & 28.9 & 28.9 \\
\hline Agree & 24 & 53.3 & 53.3 & 82.2 \\
Neutral & 5 & 11.1 & 11.1 & 93.3 \\
\hline Disagree & 1 & 2.2 & 2.2 & 95.6 \\
Strongly disagree & 2 & 4.4 & 4.4 & 100.0 \\
\hline Total & 45 & 100.0 & 100.0 & - \\
\hline
\end{tabular}

Table 5 reveals that the majority of participants agree that there is great teamwork and commitment. Managers do support employees if there are problems, but there is no involvement of supervisors in the process of recruitment of workers.

Table 6. Frequency showing the recruitment policy on quality services

\begin{tabular}{l|c|c|c|c}
\hline Recruitment policy on quality services & Frequency & Percent & Valid percent & Cumulative percent \\
\hline Strongly agree & 3 & 6.7 & 6.8 & 6.8 \\
\hline Agree & 14 & 31.1 & 31.8 & 38.6 \\
Neutral & 19 & 42.2 & 43.2 & 81.8 \\
Disagree & 4 & 8.9 & 9.1 & 90.9 \\
Strongly disagree & 4 & 8.9 & 9.1 & 100.0 \\
\hline Total & 44 & 97.8 & 100.0 & - \\
No response & 1 & 2.2 & - & - \\
\hline Total & 45 & 100.0 & - & - \\
\hline
\end{tabular}

Table 6 reveals that the municipality recruitment policy needs to be formulated to support quality services, since employees were not clear and supervisors are not included in process of selection of workers.

Table 7. Frequency showing the employee development program

\begin{tabular}{l|c|c|c|c}
\hline \multicolumn{1}{c}{ Employee development program } & Frequency & Percent & Valid percent & Cumulative percent \\
\hline Strongly agree & 11 & 24.4 & 25.0 & 25.0 \\
\hline Agree & 14 & 31.1 & 31.8 & 56.8 \\
Neutral & 11 & 24.4 & 25.0 & 81.8 \\
Disagree & 1 & 2.2 & 2.3 & 84.1 \\
Strongly disagree & 7 & 15.6 & 15.9 & 100.0 \\
Total & 44 & 97.8 & 100.0 & - \\
No response & 1 & 2.2 & - & - \\
\hline Total & 45 & 100.0 & - & - \\
\hline
\end{tabular}

Table 7 reveals that there is no need for the municipality to focus further on developing employees, as there are developed. However, a challenge is on career growth. 
Table 8. Frequency showing the good performance recognition

\begin{tabular}{l|c|c|c|c}
\hline \multicolumn{1}{c}{ Good performance recognition } & Frequency & Percent & Valid percent & Cumulative percent \\
\hline Strongly agree & 6 & 13.3 & 13.3 & 13.3 \\
\hline Agree & 11 & 24.4 & 24.4 & 37.8 \\
Neutral & 13 & 28.9 & 28.9 & 66.7 \\
Disagree & 8 & 17.8 & 17.8 & 84.4 \\
Strongly disagree & 7 & 15.6 & 15.6 & 100.0 \\
\hline Total & 45 & 100.0 & 100.0 & - \\
\hline
\end{tabular}

Table 8 reveals that supervisors need to promote recognition of good performance, which is another strategy to motivate workers.

Table 9. Frequency showing the monthly plan discussion

\begin{tabular}{l|c|c|c|c}
\hline \multicolumn{1}{c|}{ Monthly plan discussions } & Frequency & Percent & Valid percent & Cumulative percent \\
\hline Strongly agree & 6 & 13.3 & 13.3 & 13.3 \\
Agree & 6 & 13.3 & 13.3 & 26.7 \\
Neutral & 13 & 28.9 & 28.9 & 55.6 \\
Disagree & 10 & 22.2 & 22.2 & 77.8 \\
Strongly disagree & 10 & 22.2 & 22.2 & 100.0 \\
Total & 45 & 100.0 & 100.0 & - \\
\hline
\end{tabular}

Table 9 reveals that there is gap whereby workers are not taught or informed as to what is expected on them each month, as they do not meet with their supervisors at the beginning of each month for clarity.

Table 10. Frequency showing the work performance monitoring

\begin{tabular}{l|c|c|c|c}
\hline \multicolumn{1}{c}{ Work performance monitoring } & Frequency & Percent & Valid percent & Cumulative percent \\
\hline Strongly agree & 5 & 11.1 & 11.1 & 11.1 \\
\hline Agree & 8 & 17.8 & 17.8 & 28.9 \\
Neutral & 16 & 35.6 & 35.6 & 64.4 \\
Disagree & 12 & 26.7 & 26.7 & 91.1 \\
Strongly disagree & 4 & 8.9 & 8.9 & 100.0 \\
\hline Total & 45 & 100.0 & 100.0 & - \\
\hline
\end{tabular}

Table 10 reveals that there is no monitoring of work performance on a monthly basis. This finding may cause the demotivation of workers to perform at their best if their work is only monitored after a long period, or not at all.

Table 11. Frequency showing the planning with supervisors

\begin{tabular}{l|c|c|c|c}
\hline \multicolumn{1}{c}{ Planning with supervisors } & Frequency & Percent & Valid percent & Cumulative percent \\
\hline Strongly agree & 5 & 11.1 & 11.1 & 11.1 \\
Agree & 16 & 35.6 & 35.6 & 46.7 \\
Neutral & 8 & 17.8 & 17.8 & 64.4 \\
Disagree & 5 & 11.1 & 11.1 & 75.6 \\
Strongly disagree & 11 & 24.4 & 24.4 & 100.0 \\
\hline Total & 45 & 100.0 & 100.0 & \\
\hline
\end{tabular}

Table 11 reveals that the majority of participants are aware of what is anticipated of them, however, others are not aware.

Table 12. Frequency showing the promotions

\begin{tabular}{l|c|c|c|c}
\hline \multicolumn{1}{c|}{ Promotions } & Frequency & Percent & Valid percent & Cumulative percent \\
\hline Strongly agree & 20 & 44.4 & 44.4 & 44.4 \\
Agree & 17 & 37.8 & 37.8 & 82.2 \\
Neutral & 6 & 13.3 & 13.3 & 95.6 \\
Strongly disagree & 2 & 4.4 & 4.4 & 100.0 \\
Total & 45 & 100.0 & 100.0 & - \\
\hline
\end{tabular}


Table 12 reveals that the majority of the participants agree that reviewing of the promotion strategies might progress the quality of service rendered from workers.

\section{DISCUSSION OF EXTERNAL AND INTERNAL FACTORS}

\subsection{Demographic issues}

The studies of Jacobson (2010) and Ulfertsm, Wirtz, and Peterson (2009) recommend that the demographic issues need to be addressed in the public sector organizations. The result reveals that the municipality did consider empowering women at all levels, since there were the majority of workers (68.9\%) in the payroll of these customer centres. However, there was a need for these customer centres to consider gender equality, since males were $31.1 \%$. Demographic changes were regarded as one of the external factors that affect HRP, balance of skilled labor in the organization, both male and female should be considered (Dom et al., 2012). The result reveals a gap of unequal stats when it comes to race, since Blacks are $84.4 \%$ in these customer centres. Therefore, the paper identifies a gap for these customer centres to revisit their recruitment policy in terms of balancing the demographics in all centers.

\subsection{Lack of educational qualifications}

The tests in the labor market are related to recruiting and holding the quality people, especially in the public sector (DPSA, 2009). The literature revels that information about qualifications, skills, succession plans and other training gaps are identified in the system of HRP (Sharma, 2012). Therefore, it shows that the municipal managers had no qualifications and other senior officials had incorrect qualifications for those positions (Local Government Sector Education and Training Authority, 2007). The study that was conducted by Burger (2010) revealed that many employees are not qualified for their duties. However, over and above the HRP is described as a shape that redesigns qualified employee to hold the right positions in the organizations (Ghazala \& Habib, 2012).
The study revealed that employees and also supervisor hold a national certificate, which creates a norm for other employees that national certificate is a required qualification (matric) in these centers. Ngcamu (2013) stated that the education progression in the municipality was only in the townships compared to rural areas. The development was initiated, since financial assistance was given to those who wish to study further, but it was not communicated to everyone. A challenge is to communicate all the employees about these opportunities.

\subsection{Planning for retirements}

The process of HRP is not only concerned with manpower demand projections or workers turnover projections, but also helps in planning for retirements, succession planning and replacements in a systematic manner (Anyadike, 2013). The findings of the paper reveal that municipality does consider a challenge of youth unemployment and initiative was taken, since there dominated young workers who can grow within the municipality to retirement, since more than half (51.1\%) of workers were below the age of 35 years and other quarter were less than 40 years. This can be a greater strength for these customer centres to replace with experience workers the $22.2 \%$ of staff who were more than 46 years when they reached to retirement. It noted that workers working for these customer centres of municipality were loyal to stay and work for the municipality for the longer period, since the majority of staff $(37.8 \%)$ had worked for more than 6 years in these customer centres. Since these customer centres were established, only few workers were about to retire. Therefore, the municipality needs to monitor and review the current pool of workers to grow and reach to retirements. Therefore, this paper can assist these customer centres in planning for future when it comes to retirements and replacement.

\subsection{Insufficient working tools}

Technology is an issue in the workplace during change, which leads to removing workers and replacing them with technology (Xie \& Haung, 2012). The findings of the study provide inconsistent outcome, as most of the staff revealed that there were enough tools of work. It was further revealed that if there is broken equipment, it is attended quicker. 


\subsection{Working environment}

According to Macharia (2016), setting up a new regional organization and planning for new methods of working are obstacles that affect HRP. Space was revealed as another obstacle of the municipality. COGTA (2009) revealed that some of the municipalities administrations were well-resourced, while others faced enormous infrastructure backlogs. Customer centres based on their working space were not equal, somewhere located in the modern areas, while some were in rural areas. To accommodate many customers was difficult especially to some centers, and customers had to wait outside until it cleared inside. The very same obstacle also affects employees who had all the resources to work, but because of space they had to share or be in joint environment.

\subsection{Poor recruitment policies}

Organizations that have a shortage of employees end up on suffering from meeting the target, use of overtime, recalling employees who were laid off, use of part time and subcontracting, which cost the organization (Jacobson, 2010). HRP is the solution to current and future problems within the organizations by ensuring that it will have the required number of workers with the necessary skills to meet its strategic objectives. The municipalities need to hire people who will be able to deliver according to the organizational goals and standards (Koma, 2010). As the population of people increases in the country, the study revealed that in these customer centres, the existing workers feels as if they service more people than they should because of the busyness and num- ber of customers coming in daily. This finding displayed overload from workers. Shortages of workers is a serious consequence in the output and can cost the organization a lot of money through hiring temporary workers and use of overtime (Jacobson, 2010).

The municipality customer centres workers were not enough and these customer centres need to add more staff to execute the duties and meet the public needs as required by the act. Challenges faced by these customer centres were that even they had no enough staff, the only hope they had was on interns and contract staff who did add much value. However, the municipality did not renew the expired contract of workers so once a contract comes to the end, it is a goodbye to that workers, which open a gap in the customer centres of shortage of staff. It is noted that some of the interns and contractors were doing very good job, but there was no opportunity for them to be appointed as full-time workers within these customer centres, unless they apply if there was a vacant position. Anyadike (2013) revealed that HRP's role is also retaining skilled people in the organization. However, by look of things, centres still lack to retain good staff to the system, since they allowed experienced staff to leave as indicated.

\subsection{Career growth}

The result reveals that municipality has no promotion strategies implemented in place, which is an internal motivational strategy of career growth to workers. Having workers doing one job with no growth can lead to dissatisfaction as refereed in two factor theory.

\section{CONCLUSION}

Obstacles of HRP include both internal and external factors that affect workers in delivering services to public. Institutions need to rethink in rebuilding an environment that promotes quality services to public through workers. The hygiene factors produce dissatisfaction, and the municipality needs to ensure satisfaction within the centers to operate smoothly. Municipality needs to plan for new conducive housing that can accommodate more workers with their own work stations and equipment. Strategies of academic development need to be created and implemented to workers to motivate employees and benefit in the promotion exercise. Not progressing academically is also another obstacle that affects employees in pursuing to senior positions. Findings reveal that recognition was poor and can lead to low staff morale, therefore, recognition strategies need to be reviewed. To be an employer of choice, municipality needs to create and implement promotion strategies to develop and promotes workers, since findings reveal that there were no promotion opportunities in these centres of the municipality. 


\section{ACKNOWLEDGEMENT}

Special acknowledgment goes to the officials of the municipality for permitting me with a chance to conduct this kind of research within their premises.

\section{REFERENCES}

1. Al-Wahshi, A., Omari, M., \& Barrett, R. (2013). Human Resource Planning: Sector Specific Consideration. Public Sector and Not-for-profit. Retrieved from https://ro.ecu.edu.au/cgi/viewcontent.cgi?referer=https://www. google.com.ua/\&httpsredir=1\&art icle $=1257 \&$ context $=$ ecuworks 2013

2. Auditor-General Report (2011). Integrated Development Plan (2011-2016). EThekwini Municipality. Retrieved from http://www.durban.gov.za/City_ Services/sizakala_customer_care/ Pages/default.aspx

3. Auditor-General Report (2012). Draft Integrated Development Plan: Annexure 9. EThekwini Municipality. A. \& Huang, X. (2012) Advances in Computer Science and Education. London: Springer. Retrieved from https:// www.agsa.co.za/Portals/0/ MFMA\%202012-13/2012_13_ MFMA_Consolidated_general_report.pdf

4. Colley, L., \& Price, R. (2010). Where have all the workers gone? Exploring public sector workforce planning. Australian Journal of Public Administration, 69(2), 202-213. https://doi.org/10.1111/ j.1467-8500.2010.00676.x

5. Dom, N., Kasim, N., \& Shamsuddin, A. (2012). Framework of human resource planning (HRO) influencing factors for local workforce supply in Malaysian construction industry. Journal of Technology Management in China, 7(2), 177-197.

6. Ghazala, L., \& Habib, J. (2012). Human Resource Strategies. Journal of Business and Management, 3(6), 6-13.

7. Jacobson, W. (2010). Preparing for tomorrow: a case study of workforce planning in North
Carolina municipal governments Public Personnel Management, 39(4), 1-21. https://doi.org/10.117 7\%2F009102601003900404

8. Koma, S. B. (2010). The State of Local Government in South Africa Issue, Trends and Options. School of Public Management and Administration. Journal of Public Administration, 45(1), 111-120. Retrieved from https://hdl.handle. net/10520/EJC51773

9. Macharia, A. L. W. (2016). Factors influencing Human Resource Planning among insurance firms in Kenya. School of Business, University of Nairobi.

10. Maina, D. K., \& Kwasira, J. (2015). Role of Human Resource Planning practices on employee performance in country governments in Kenya: A case of Nakuru Country. International Journal of Economics, Commerce and Management, 3(5), 15691580. Retrieved from http:// ijecm.co.uk/wp-content/uploads/2015/05/35103.pdf

11. Makanyeza, C., Kwandayi, H. P., \& Ikobe, B. N. (2013). Strategies to improve service delivery in local authorities. International Journal of Information Technology and Business Management, 15(1). Retrieved from https:// www.researchgate.net/publication/253240244_Strategies_to_improve_service_delivery_in_local_authorities

12. Manwunga, A. K. (2011). The role of human resource manager in the public service in promoting professionalism and implementing the charter for public service in Africa. Ethiopia: Addis Ababa.

13. Mdlongwa, E. T. (2014). Local Government at the heart of poor service delivery. Public Service Accountability Monitor (PSAM).
Retrieved from https://www.ru.ac. za/psam/publications/

14. Mpofu, M., \& Hlatywayo, C. K. (2015). Training and Development as a tool for improving basic service delivery: the case of a selected municipality. Journal of Economics, Finance and Administration Science, 20(39), 133-135. https://doi.org/10.1016/j. jefas.2015.10.004

15. Mugambi, J. (2014). Service quality dimension in health care service delivery: the case for Healthstrat in Kenya (MBA Unpublished dissertation). Nairobi: University of Nairobi.

16. Naris, S. N., \& Ukupere, W. I. (2009). The effectiveness of an HR code: staff development and training at the Polytechnic of Namibia (Business Papers and Report). Cape Peninsula University of Technology.

17. Ndebele, C., \& Lavhelani, P. N. (2017). Local Government and Quality service delivery: An Evaluation of Municipality in Limpopo Province. Journal of Public Administration, 52(2), 340 356. Retrieved from https://journals.co.za/content/journal/10520/ EJC-bf4ce318a

18. Nealer, E. (2014). Local government and service delivery in Gerrit van der Walt. In Municipality management: service the people (2nd ed.) (JUTA, pp. 162-180). Claremont.

19. Ngcamu, B. S. (2013). The Paradox of the Regional Centres Unit: The case of the eThekwini Municipality. Journal of Economics and Behavioral Studies, 5(7), 432-438. Retrieved from https:// www.researchgate.net/publication/273219253_The_Paradox_of_ the_Regional_Centres_Unit_The _ Case_of_eThekwini_Municipality 
20. Nisha, S. (2009). The need for continues (computer-based) training and development of library staff in a public library (Unpublished dissertation). Pretoria University of South Africa.

21. Norman-Majorm, K., \& Gooden, S. (2012). Cultural Competency for Public Administrators. M.E. Sharpe Incorporated. New York: Armonk.
22. Pretorius, D., \& Schurink, W. (2007). Enhancing service delivery in local government: The case of a district municipality. SA Journal of Human Resource Management, 5(3), 19-29. https://doi. org/10.4102/sajhrm.v5i3.148

23. Ulfertsm, G., Wirtz, P., \& Peterson, E. (2009). Strategic human resource planning in academia. American Journal of Business Education, 2(7), 1-9. Retrieved from https://eric. ed.gov/?id=EJ1052648

24. Xi Anyadike, N. O. (2013). Human Resource Planning and employee productivity in Nigeria Public organizations. Global Journal of Human Resource Management, 1(4), 56-68. 